\title{
CRITICISM TOWARDS SHAHRŪR'S CONCEPT OF THE PROPHET'S SUNNAH
}

\author{
Fahmi Ali Syaifuddin Rizal \\ Universitas Islam Negeri Sunan Ampel Surabaya, Indonesia \\ E-mail: fahmialisyaifuddinrizal07@gmail.com
}

\begin{abstract}
This article deals with the concept of Sunnah proposed by Muhammad Shahrūr and offers a criticism towards his tendency to the denial of the Prophet's Sunnah (inkār al-Sunnah). Shahrūr rejects the Hadìth and Sunnah as the second source of Islamic law, by reformulating and redefining the concept of Hadith and Sunnah. Shahrūr distinguished between Hadīth and Sunnah. According to him, the Hadith is the Qur'ān itself, and the Sunnah has been the practical application (ijtibajd) of the Prophet to implement what was revealed to him. Shahrūr's rejection and denial of Hadīth and Sunnah are based on the argument that all Hadiths were filled with the story of Isrā'iliyyāt. The tendency towards inkār al-Sunnah represented by Shahrūr is not a completely new idea, since this position was also conceived by several previous figures. However, despite the fact that Shahrūr's inkär al-Sunnah as argued on the basis of new approach to Hadith studies, this article reveals that Shahrūr's understanding of, and his tendency to deny, Hadiths or Sunnah reflect his opposition against orthodox views on the Prophet's Sunnah.
\end{abstract}

Keywords: Shaḥrūr; Hadīth; Sunnah; inkār al-Sunnah.

\section{Introduction}

Hadith or Sunnah (the Prophet's Tradition) is the second source of Islamic law after the Qur'ān, and serves as the explanation of every things mentioned globally in the latter. ${ }^{1}$

\footnotetext{
1 'Abd al-Wahhāb Khalāf, Tlm Ușūl al-Fiqh (Mesir: Maktabat al-Da'wah, n.d.), 36-38.
} 
Scholars often state that the Qur'ān needs Hadīth, ${ }^{2}$ as there are many general laws mentioned in the Qur'ān which require detailed explanation from Hadīth. ${ }^{3}$

The problem of understanding the concept of the Hadith is a very important to raise, and has been discussed extensively by scholars as found in various Hadìth literature. However, it would be quite interesting to discuss the perspective of Shahrūr, who does not have a coherent religious education background, but instead a professor and expert in the field of geology of Civil Engineering.

Shahrūr has proposed a new concept of Hadìth and Sunnah, and has regarded them as being not the second source of law in Islam. His critical point of view with a strong grammatical analysis leads him to believe that there are no synonymous words ('adam altaräduf) in Arabic. His distinctive thought on the issue as presented in his scholarly works is worthy to be read and reviewed critically. Shahrūr has deconstructed an understanding of the Hadìth and Sunnah which has been rooted in the Muslim minds for many centuries. In his view, what was formulated by early (salaf) scholars in the past has been a mistake and not relevant for this time.

Based on the background above, this article seeks to investigate the concept of Sunnah (al-Sunnab) according to Shahrūr. It will further explore Shahrūr's work, as Shahrūr is remembered for his concept of Sunnah. This study reveals Shahrūr's reasons and arguments about Sunnah which includes such definitions as that the Hadith is the Qur'àn, the Sunnah

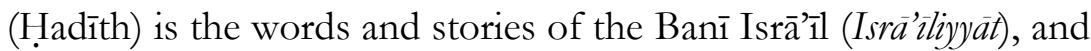
is the result of the Prophet Muhammad's intellectual endeavor (ijtihäd). Therefore, the Hadith is tentative and changing according to the time, and it is possible to be wrong. The focal point of the examination lies in the reasons and contentions in dismissing the Sunnah. In this context, this article argues that the reasons

\footnotetext{
2 Makhūl berkata: “Qur'ān needs Sunnah more than Sunnah to the Qur'ān.” See al-Khātịb al-Baghdādī, al-Kifāyah fì Tlm al-Riwāyah (Beirut: Dār al-Kutub al'Ilmìyah, 2006), 19.

3 Mannā' b. Khalīl al-Qațān, Mabāḥith fì 'Ulūm al-Qu'rān (Beirut: Maktabat alMa'ārif, 1421/2000), 361; Muḥammad b. 'Abd Allāh Abū Bakr b. al-'Arabī, Ạ̣kām al-Qu'rān, Vol. 2 (Beirut: Dār al-Kutub al-'Ilmīyah, 1424/2003), 52.
} 
advocated by Shahrūr on the concept of Sunnah are problematic, and even not valid, because Shahrūr has manipulated the Hadìth as an argument, even misunderstood and misinterpreted the language and words of the Qur'ānic verses. In this regard, Shahrūr has developed a tendency towards denying the Prophet's tradition (inkär al-Sunnab) which will be also critically assessed.

\section{Biography of Muhammad Shahrūr}

Muhammad Shahrūr b. Da'b is the full name of Shahrūr, or better known as Shahrūr. He was born in the city of Damascus, Syria on April 11, 1938. ${ }^{4}$ Shahrūr started his academic education in elementary level at the educational institution 'Abd al-Raḥmān alKawākibī, Damascus. His secondary education was completed in 1957. Shahrūr then continued his studies in Civil Engineering (handasah madaniyah) in Moscow, USSR (now Russia) with a scholarship from the Syrian Government. The Diploma level was taken for five years starting from 1959, ${ }^{6}$ until reaching a Diploma degree in 1964. ${ }^{7}$ In 1968, Shahrūr took the Master and Doctoral Program in the field of land and geology at Ireland University. Shahrūr obtained his Master of Science degree in 1969 and his Doctoral degree in $1972 .^{8}$

Shahrūr is getting interested in Islamic studies, especially since he was in Dublin, Ireland (1970-1980). From then on, Shahrūr has begun to study the Qur'ān more seriously with theories and approaches such as linguistic, philosophy, and modern science. ${ }^{9}$

\footnotetext{
4 Ahmad Syarqawi Ismail, Rekonstruksi Konsep Wabyu Mubammad Syahrur (Yogyakarta: eLSAQ Press, 2003), 43.

${ }^{5}$ Muhammad Shahrūr, Epistimologi Qur'ani: Tafsir Kontemporer Ayat-ayat al-Qur'ān Berbasis Materialisme-Dialektika-Historis, translated by M. Firdaus (Bandung: Penerbit Marja, 2015), 5.

6 Muhammad Shahrūr, Islam dan Iman: Aturan-aturan Pokok, translated by M. Zaid Su'di (Yogyakarta: Penerbit Jendela, 2002), xiii.

7 Muhammad Munīr al-Ṣawwāf, Tahāfut al-Qirāah Mu'ạsirah (Limmasol-Cyprus: al-Shawwāf li al-Nashr wa al-Dirāsāt, 1993), 29-35; Zainal Abidin, Rethinking Islam dan Iman (Banjarmasin: IAIN Antasari Press, n.d.), 18.

8 Abdul Mustaqim, Epistemologi Tafsir Kontemporer (Yogyakarta: LKiS, 2010), 94; M. Awnul Abid Shah, Islam Garda Depan; Mozaik Pemikiran Islam Timur Tengah (Bandung: Mizan 2001), 237.

9 Peter Clark, "The Shahrur Phenomenon; A Liberal Islamic Voice from Syria," Islam and Christian-Muslim Relations, Vol. 7. No. 3 (1996), 341.
} 
He studied Philosophy of Humanism, Philosophy of Language, especially contemporary linguistics and Semantics of Arabic Language..$^{10}$ Shahrūr's controversial thinking cannot be separated from the influence of previous linguistic figures, such as Ibn Fāris, Yahyā b. Tha'lab, Abū 'Al̄̄ al-Fārisī, Ibn Jinnī, 'Abd al-Qāhir alJurjānī, and Ja'far Dakk al-Bāb. ${ }^{11}$

Shahrūr's works on Islamic studies, particularly related to the Qur'ānic and Hadīth studies, include among others: al-Kitāb wa alQur'àn: Qirāàh Mu'ạsirah (1990), Diräsab Islämīyah Mu'ạsirah fì alDawlah wa al-Mujtama' (1994), al-Isläm wa al-İmān: Manzümat alQiyām (1996), Naḥw Usūul Jadìdah li al-Fiqh al-Islami: Figh al-Mar'ah (2000), Tajfíf Manäbi' al-Tarbīb (2000), al-Sunnah al-Rasülīyah wa alSunnah al-Nabawiyab: Ru'yah Jadidah (2012). ${ }^{12}$

However, Shahrūr has been also subject of critical studies, example Mujarrad al-Tanjim al-Qur'ān li Duktūr Muḥammad Shaḥrür by Sālim al-Jabī, Tahäfut al-Qirā'ah al-Mu'ạsirah by al-Șawwāf, as well as subject of appreciation as found in The Shahrür Phenomenon: a Liberal Islamic Voice from Syria by Peter Clark. The criticism often leads him to be labeled and accused of being as a Zionist, Marxian, and proponent of inkār al-Sunnab. ${ }^{13}$

\section{Shahrūr's Views on Sunnah}

In his al-Sunnah al-Rasüliyah wa al-Sunnah al-Nabawiyah and alKitäb wa al-Qur'ān: Qiräah Mu'așirah, Shahrūr explains his thoughts about the concept of inkar al-Sunnah which include the definition and new interpretation of Hadīth. Shahrūr rejects the Hadīth as the second source of law and its codification by the Prophet's companions.

\footnotetext{
10 Vita Fitria, "Komparasi Metodologis Konsep Sunnah Menurut Fazlur Rahman dan Muhammad Syahrur," Asy-Syir'ab: Jurnal Ilmu Syariah dan Hukum, Vol. 45, No. I2 (Juli-Desember 2011), 1341-1342.

${ }_{11}$ Mustaqim, Epistemologi Tafsir, 96.

12 Muḥammad Shahrūr, Prinsip dan Dasar Hermeneutika al-Qur'an Kontemporer, translated by Sahiron Syamsuddin (Yogyakarta: eLSAQ Prees, 2008); Muhammad Shahrūr, Metodologi Fiqih Islam Kontemporer, terj. Sahiron Syamsuddin, (Yogyakarta: Kalimera, 2015), 547.

${ }^{13}$ Kurdi et al., Hermenetika al-Qur'an dan Hadis (Yogyakarta: Elsaq Press, 2010), 288.
} 
Shahrūr stated that the definition of the "first Hadith," according to the people at the time of the Prophet is the Qur'an itself (al-tanzill al-hakim), because the word "Hadith" is taken from the verses of the Qur'ān. ${ }^{14}$

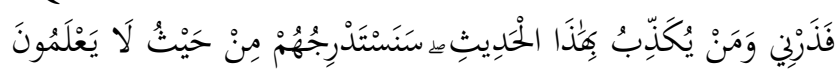

"Then leave it (hi Muhammad) to Me (the affairs) of those who deny this word (al-Qur'ān). Later We will pull them gradually (towards destruction) from a direction they do not know" (al-Qalam [68]: 44).

Shahrūr also stated the meaning of the "second Hadīth" in the Qur'ān is a story and news. ${ }^{15}$

$$
\text { هَاْْ أَتَكَ حَدِيثُ الجُنُْوِ }
$$

"Have you come to the news of the naysayers" (al-Burūj [85]: 17).

Thus, Hadith and Sunnah are the stories from the results of the Prophet's interaction with events in certain situations during his lifetime (historical products). Therefore, the Prophet and his companions did not consider Hadith to be the revelation from God. ${ }^{16}$

Shahrūr then asserted that the meaning of the "third Hadìth" is " $m \bar{a}$ dhahaba ilayh al-nabi," which means all forms of prophetic ijtihäd. ${ }^{17}$ Shahrūr argued with a Hadīth which reads:

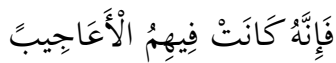

"In fact they ( Banī Isrā̄îl) have miracles."

Shahrūr maintained that the new definition of Hadìth consists of three phrases: the first is ordering to hear about the verses of the Qur'an; the second is urging them to convey what they heard from him about the verses of the Qur'ān (al-tanzill al-hakim) which was revealed to the Prophet; and the third is threatening the person who lied with his tongue then relating him even though he never said it by threatening him (the person who lied) to occupy the place in hell.

\footnotetext{
14 Muhammad Shahrūr, al-Sunnah al-Rasūlīyah wa al-Sunnah al-Nabawīyah (Beirut: Dār al-Sāqī, 2012), 22.

15 Ibid., 22.

16 Shahrūr, al-Kitāb wa al-Qur'ān, 546.

17 Shahrūr, al-Sunnah al-Rasūlìyah, 22.
} 
There is a misinterpretation of the the definition of Hadith from the two phrases above. Shahrūr claims that revelation has two sources after they transfer the command and punishment from the context of the verses of the Qur'ān exclusively to the context of the Prophet's Hadith. In the second phrase, the Prophet's Hadìths are all mudraj (included words) and very clear from the Prophet's Hadīth narrated from Jābir b. 'Abd Allāh written in the Musnad al-Shäfit (Hadith number 1.177) and the narrations from Zayd b. Aslam in the Musannaf 'Abd al-Razzaqq (Hadīth number 10.158), ${ }^{18}$ which reads:

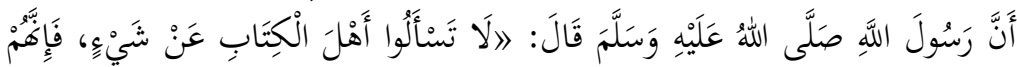

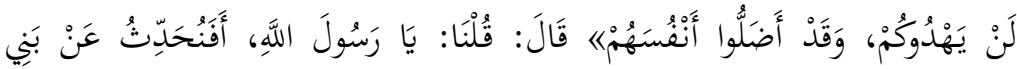

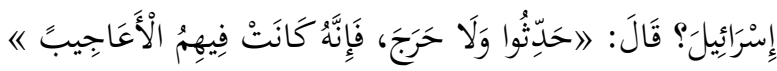

"Narrated from Jābir b. Abd 'Allah, the Rasulullah said: 'Do not ask anything to the people of the book, in fact they will not guide you, because they have gone astray," Jābir said: 'we said: $\mathrm{Hi}$, Rasulullah what can we tell the story of Banī Isrā'îl?' Rasul said: 'tell (the story of Banī Isrā̄îl) and you are not sinful (that is okay), Verily they (Banī Isrā'îl) have miracles."

In this regards, the Hadith will be filled with the stories of isrā'iliyāt (the Biblical stories) which assume that their news is holy news, and accordingly contradicts the testimony of the Prophet Muhammad that the news from Banī Isrāîl is false news. ${ }^{19}$

Shahrūr made the first interpretation of the verse the Qur'ān and stated that neither Hadīth nor Sunnah included revelation from Allah. Therefore, he did not consider the term "al-waby althan $\vec{\imath}$ " (the second revelation) for the Hadiths or Sunnah of the Prophet Muhammad. This opinion is built on the interpretation of God's word:

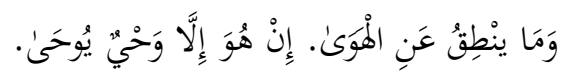

“And that is not what he said (the Qur'ān) according to the his lust willing. These utterances were nothing but revelations which were revealed (to him)" (al-Najm [53]: 3-4).

\footnotetext{
18 Ibid., 21-22.

${ }^{19}$ Ibid., 22.
} 
Shahrūr argued that the evidence that the Hadith as the second source with the verses of al-Najm above is not justified. This is because the meaning of showing damir (pronoun) "buwa" in this verse is clearly refered to al-Qur'ān and not to the Prophet Muhammad. There is no connection between the previous damir and the damir in the verb "yantiqu" which is interpreted as a word that denotes a return to the Prophet. It is in accordance with the nature of the Prophethood that the Prophet was not a determinant of law that could be carried out by the words and the Prophet's deeds which include his desires as well as the fluctuating state of his soul. ${ }^{20}$

Shahrūr made a second interpretation of the verse and stated that the Hadith is " $m \bar{a}$ dhahaba ilayh al-nab $\vec{\imath}$ " which means all forms of prophetic ijtihäd. As Allah has said, it is as a clear warning to the Prophet when the Prophet's ijtihad could not be tolerated on several occasions or in other words the Prophet committed wrong ijtibād: ${ }^{21}$

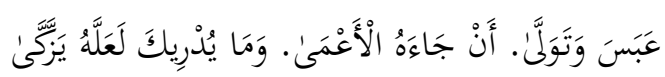

"He (Muhammad) was surly and turned away. because a blind man had come to him. Did you know maybe he wanted to clean himself (from sin)" ('Abasa [80]: 1-3).

In other verses, the Prophet was also reminded by God as follows:

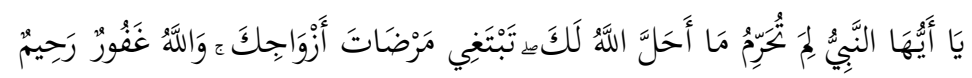

"Hi Prophet, why have you forbidden what Allah has made lawful for you; you are looking for the pleasure of your wifes? And Allah is Forgiving, Most Merciful" (al-Tahrīm [66]: 1).

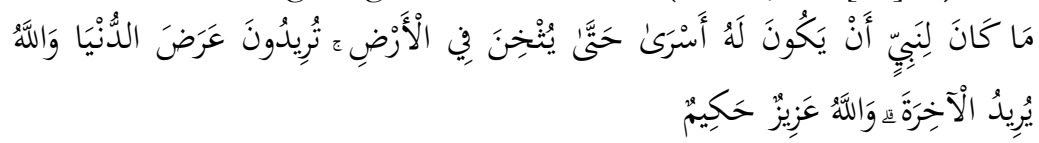

"It is not appropriate, for a Prophet to have prisoners before he can paralyze his enemies on earth. You want worldly possessions while Allah wants (reward) the after life (for you). And Allah is Mighty, Most Wise" (al-Anfāl [8]: 67).

\footnotetext{
${ }^{20}$ Shahrūr, al-Kitāb wa al-Qur'àn, 546.

${ }^{21}$ Ibid., 546.
} 
Shahrūr made a third interpretation of the verse and asserted that a group of scholars who stated that the Prophet Muhammad had ordered to collect and record his words to avoid mixing the revelations (the Qur'ān) with Hadith is a weak opinion. Because the Prophet was the first to understand the words of Allah and the Qur'ān that has been guarded by Allah:

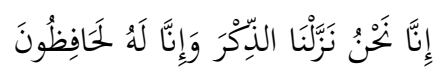

“Truly, We are the ones who sent down the Qur'ān, and truly We really do preserve it" (al-Hijr [15]: 9).

With this verse as a proof, Shahrūr argued that the Prophet should have had an idea to assign some companions to write revelations (the Qur'ān) and some others to write Hadìth. ${ }^{22}$

After the companions finished the collection of the Qur'ān, which started in the period of Abu Bakr until the end of the 'Uthmān b. 'Affān's period, then the muș̣af was copied. The collection and writing had been complete, and the present mushaf is the copy of the first mushaf. Then, why did the companions not collect the Hadiths at that time as they collected the verses of the Qur'ann after they had free time, that is after collecting and writing the verses of the Qur'ān? Thus when that happens the Hadith will also come to us with a mutawatir narrative.

If the Prophet and the companions did not collect and write Hadith for the reason above, it means that the collection of Hadiths was unnecessary and unimportant. It can be concluded that the Hadith of the Prophet is a historical product and the Sunnah is not the true word of the Prophet.

It can be understood that if there was no order from the Prophet to collect and codify Hadiths, it can be concluded that the Prophet and his companions wanted to confuse Muslims with the absence of codification of Hadīth. It means that the Qur'ānic verse in al-Măidah [5]: 3 is meaningless. Thus, how is this religion complete if the Hadith as the source of the second law has not been codified? How come the companions have written the Qur'ān but the Hadìth has not been codified? ${ }^{23}$

\footnotetext{
22 Ibid., 547.

23 Ibid., 547.
} 
Shahrūr made the fourth interpretation of the verse and stated that a guideline or method based on an agreed pattern of life then applied to society in order to be easily implemented. As a consequence, the Sunnah changes and transforms, because the Qur'àn explains that the Sunnah is not eternal, even tentative (changing). The Qur'ān mentions as follows (al-Anfāl [8]: 38, alHijir [15]: 13, al-Kahfi [18]: 55, al-Ahzāb [33]: 38, Ghāfir [40]: 85, Āli 'Imrān [3]: 137, and al-Nisā’ [4]: 26): ${ }^{24}$

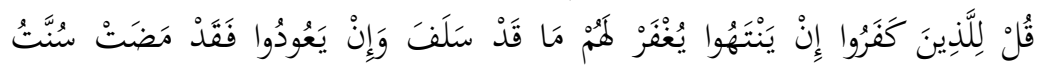

"Say to those who disbelieve: "If they stop (from disbelief), surely Allah will forgive them about their past sins; and if they come back again it will actually apply (to them) the Sunnah (of Allah towards) the former people" (al-Anfâl [8]: 38).

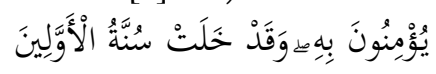

“They do not believe it (al-Qur'ān) and indeed the sunnatullah has passed on the people before" (al-Hijr [15]: 13).

Therefore, the concept of Islam as the religion that applies to any time and place (säliḥ li kulli zamān wa makān) would necessarily interact with circumstances and historical stages to produce a particular society and civilization at each era. In this case, the principle of historical civilization can be taken according to the people who interact with it. It is the main reason for the Prophet and his companions in emphasizing their attention to revelation which is a fundamental principle, while the rest is left to humans in the course of time.

In this regard, it would be not correct to define the Prophet's Sunnah as all things that comes from the Prophet in the form of words, deeds, orders, prohibitions, or agreements. The definition of Sunnah as such does not come from the Prophet himself, and therefore it is subject to discussion, acceptance or even rejection. Such a definition implies that the Prophet and his companions did not have knowledge about the Sunnah as defined above. It is therefore more appropriate to argue that the basis or source of

${ }^{24}$ Shahrūr, al-Sunnah al-Rasūìyah, 93-94. 
Islamic law is the Qur'ān and the Sunnah, rather than the Qur'ān and Hadìth. ${ }^{25}$

\section{Criticism towards Shaḥūr's Inkār al-Sunnah}

Shahrūr's rejection of Hadìth as the second source of Islamic law and the concept of Sunnah which changes every time seems worthy of re-examination. It is because in the Hadith there are several sources of Islamic law that are in accordance with what is written in the Qur'ān. Hadīth also serves as reinforcing ( $t a^{\prime} k i \bar{d}$ ) what has been determined by the Qur'ān, as clarifying or explaining (tabyin) what is contained in the Qur'ān, and as determining the laws that have not been regulated or laws that have not been legally enforced in the Qur'ān. ${ }^{26}$

The first definition proposed by Shahrūr that the Hadīth is the Qur'ann itself is comparatively incorrect. The root of the word Hadith (al-Hadith) is haddatha-yuhaddithu which means expression or word, ${ }^{27}$ while, the words or expression referred to al-Qalam [68]: 44 are attributed to the Qur'ān (kaläm Alläh). ${ }^{28}$

The meaning of the word "hadīth" is the Qur'ān, but it does not mean that the Hadìth is the Qur'ān itself. The word "hadīth" is used instead of the word "qur'ān," because at that time the process of revelation (the Qur'ān) was not complete yet. It had not been fully codified and called the Qur'ān because it was still kaläm Allāh that came down gradually, verse by verse, during the early days of Islam. ${ }^{29}$ It can also be proven by the category of the al-Qalam [68]

\footnotetext{
${ }^{25}$ Shahrūr, al-Kitāb wa al-Qur'àn, 548.

26 Muhammad Abū Zahw, al-Hadìth wa al-Muhaddithūn (Kairo: Dār al-Fikr al'Arabī, 1378), 38-39. Muḥammad Jamāl al-Dīn b. Muḥammad Sa'īd b. Qādim alHalāq al-Qāsimī, Qawāí al-Tạ̣dìth min Funūn Muștalạ̣ al-Ḥadìth (Beirut: Dār alKutub al-'Tlmìyah, n.d.). 149.

27 Aḥmad Mukhtār 'Abd al-Hamīd 'Umar, Mu'jam al-Lughab al-'Arabìyah alMu'àsirah, Vol. 1 (N.p.: 'Ālim al-Kutub, 1429), 454.

${ }^{28}$ Muḥammad b. Jarīr b. Yazīd b. Kathīr b. Ghālib al-Amalī Abū Ja far al-Ṭabarī, Jämi al-Bayān fi Ta'mül al-Qurān (Tafsìr al-Ṭabari), Vol. 23 (N.p.: Mu'assis alRisālah, 1420), 561; Abū Muhammad al-Husayn b. Mas'ūd b. Muhammad b. alFarā' al-Baghawī al-Shāfí̄i, Ma'älim al-Tanzīl fi Tafsìr al-Qur'ān (Tafsìr al-Baghawì), Vol. 5 (Beirut: Dār Iḥyā’ al-Turāth al-'Arabī, 1420), 142.

${ }^{29}$ Muḥamamd 'Abd al-'Ażīm al-Zurqānī, Manāhil al-Irfān fì 'Ulüm al-Qừ'ān, Vol. 1 (N.p.: Maṭba' 'Īsā al-Bānī al-Ḥilmī, n.d.), 19; Muḥammad Bakr 'Ismā'īl, Dirāsāt fì 'Ulūm al-Qưr'ān (N.p.: Dār al-Manār, 1419), 10.
} 
that is included into Makkiyah (revealed during Meccan period) which means the surah came down before the prophet's emigration (bijrab) to Madinah. ${ }^{30}$ This verse tells about the situation of the Prophet in Mecca at that time as the opposition from the infidels of Quraysh was quite strong. This verse has been abolished (nasakb) by the verses of al-sayf (which indicate that Muslims must fight when they are threatened), as mentioned in al-Tawbah [9]: 5, 36, and $41 .^{31}$ The use of arguments have been abrogated (mansükb) for an argument (bujjah) not allowed in Islam, because the abrogation (nasakh) itself is meant as constructing a new law with arguments based on Shari' ${ }^{-6}$ h, and abandoning or canceling the law from the arguments that have been abrogated (mansükb). In this regard, Shahrūr's arguments are rejected (mardūd) accordingly. ${ }^{32}$

The evidence for this matter is that the use of the word "qur'ān" in the Qur'ān has the meaning the Qur'ān itself, which is found in the Medinan chapter (sürah Madaniyah). This also shows that the surah came down when the Prophet had emigrated to Medina (even though it was in Mecca), such as the verse in alBaqarah [2]: 185, al-Nisā’ [4]: 82, al-Mā’idah [5]: 101, and alTawbah [9]: 111. ${ }^{33}$

The second definition proposed by Shahrūr that the Hadith is a story, news and interpreting as a historical product by relying

\footnotetext{
30 Abū 'Abd Allāh Badr al-Dīn Muḥammad b. 'Abd Allāh b. Buhādir alZarkashī, al-Burhān fì 'Ulūm al-Qur'ān, Vol. 1 (Beirut: Dār Ihyā' al-Kutub al'Arabīyah, 1376), 187; Abū al-Qāsim b. Salāmah b. Naṣr b. 'Alī al-Baghdādī alMuqrī, al-Nāsikh wa al-Mansūkeh (Beirut: al-Maktabat al-Islāmī, 1404), 183.

31 Abū Muḥammad 'Alī b. Aḥmad b. Sa'īd b. Hazm al-Andalusī al-Qurtubī alZāhirī, al-Näsikh wa al-Mansükeh fì al-Qur'àn al-Karìm (Beirut: Dār al-Kutub al'Ilmīyah, 1406), 61. Jamāl al-Dīn Abū al-Farj 'Abd al-Rahmān b. 'Alī b. Muhammad al-Jawzī, al-Musfì bi Akefi Abl al-Rasükh min Tlm al-Nāsikh wa alMansükh (N.p.: Mu'assisat al-Risālah, 1418), 57.

32 Qatādah b. Di'āmah b. Qatādah b. 'Azīz Abū al-Khațāāb al-Sudūsī al-Bașrī, alNäsih wa al-Mansükeh (N.p.: Mu'assisat al-Risālah, 1418), 6; Muhammad b. Husayn b. Ḥasan al-Jīzānī, Ma'älim Ușūl al-Figh Inda Abl al-Sunnah wa al-Jamā'ah (N.p.: Dār Ibn al-Jawzī, 1427), 246. Khalāf, Tlm Ușūl, 222. 'Abd al-Mālik b. 'Abd Allāh b. Yūsuf b. Muḥammad al-Jawīn̄, al-Burhān fì Usùl al-Figh, Vol. 2 (Beirut: Dār al-Kutub al-'Ilmīyah, 1418), 246.

33 Abū 'Abd Allāh al-Hārith b. Asad al-Muhāsibī, Fahm al-Qưrān wa Ma'ānīhi (Beirut: Dār al-Kindī, 1398), 395. Faḥd b. 'Abd al-Raḥmān b. Sulaymān al-Rūmī, Dirāsāt fì 'Ulūm al-Qur'àn al-Karim (N.p.: Ḥuqūq al-Ṭab' Maḥūẓah, 1424), 125.
} 
upon al-Burūj [85]: 17 , is not true. It is due to the fact that the root of the word "hadith" is ḥaddatha-yuhaddithu which means speaking, preaching, and informing. ${ }^{34}$ The meaning of the word "hadìth" refers to everything that has been discussed about words and report (news)..$^{35}$

If Shahrūr interprets "hadīth" linguistically as news, it is in accordance with the original (literal) meaning of the term. However, it is well-known that the definition of the Hadith terminologically or in the science of Hadith is anything (in the form of news) that comes from the Prophet Muhammad which includes words, deeds, consent and behavior. ${ }^{36}$ When Shahrūr defines or explaines the Hadith as stories and historical products regarding the Prophet's interaction with events and certain situations, then it cannot justified. It is because the Hadith contains the words, deeds and behavior of the Prophet which are conveyed in two phrases which include sanad (chain of transmission) and matn (content). ${ }^{37}$ Shahrūro's definition of the Hadith as stories and news (reports) is not correct, since the meaning of "hadīth" in al-Burüj [85]: 17 cannot be used to define the term the Hadith as stories and historical products. In the following verse, Allah reminds the Prophet with news about the events or incidents of people, such as Fir'aun, his people, and the Thamūd. In this regard, Allah chooses the word "hadìth" instead of the word "akhbār." 38

\footnotetext{
${ }^{34}$ Nashwān b. Sa‘īid al-Hamīrī al-Yamanī, Shams al- 'Ulüm wa Dawa' Kalām al-'Arab min al-Kalūm, Vol. 3 (Beirut: Dār al-Fikr al-Ma'āṣir, 1420), 1361; Louwis b. Naqula Zāhir al-Ma'lūf, al-Munjid fì al-Lughah (Beirut: al-Maṭba'ah alKāthulīkìyah, 2010), 121.

35 'Umar, Mu'jam al-Lughah, Vol. 1, 454; Sa'dī Abū Habīb, al-Qāmūs al-Fiqhìyah Lughah wa Istitlāh (Damascus: Dār al-Fikr, 1408), 79.

${ }^{36}$ Muḥammad b. Șāliḥ b. Muḥammad al-'Uthaymin, Muṣtalạ̣ al-Hạith (Kairo: Maktabat al-'Ilm, 1415), 5.

37 Zayn al-Dīn 'Abd al-Raḥmān b. Aḥmad b. Rajab b. al-Ḥasan al-Salamī, Sharḥ Tla al-Tirmidhì (Yordania: Maktabat al-Manār, 1407), 156.

38 Abū Muḥammad 'Abd al-Raḥmān b. Muḥammad b. Idrīs b. al-Mundhīr alTamīmī b. Abī Hātim al-Rāzī, Tafsìr al-Qur'ān al-'Ažìm li Ibn Abì Hātim, Vol. 10 (Saudi Arabia: Maktabat Naẓār Muṣtafā al-Bāz, 1419), 3414; al-Ṭabarī, Jāmi‘ alBayān, Vol. 24, 346-347.
} 
The third definition proposed by Shahrūr that Hadīth is "mā dhahaba ilayh al-nabi," which means all forms of the Prophet's endeavor (ijtibād), and Shahrūr's view that all Hadìths are mudraj and filled with the words and deeds of Banī Isrā̄îl cannot be accepted. Supposedly, those who reject Hadith and Sunnah disregard the Prophet's Hadīth as their argument (bujjab), but it is ironic that they base their argument to reject Hadith on the Hadìth itself.

In this context, Shahrūr's argument against Hadīth and Sunnah is based on the Prophet's Hadīth narrated by Jābir b. 'Abd Allāh in the Musnad al-Shäfic number 1.177 and the narration of Zayd b. Aslam in the Musannaf 'Abd al-Razzāq number 10.158. Confirming these books, Shahrūr maintains that it can be concluded that the Shahrūr who did the Hadìth is mudraj, since in the Musannaf 'Abd al-Razzāq number 10.158 there is no word "fa innabü kanat fi bim ala "ajib" as the following:

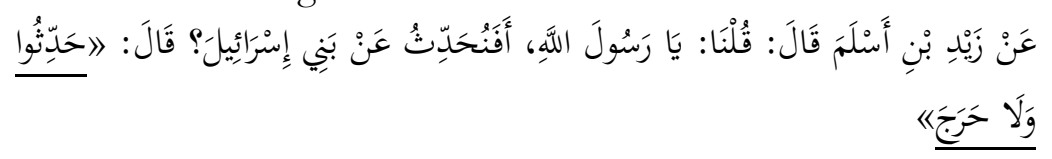

"From Zayd b. Aslam said: 'we say are we allowed to tell about the Banī Isrā'îl?,' The Prophet said: 'tell (what you hear) from Banī Isrā̄il and that is okay (no sin)" (Narrated by "Abd alRazzāq). ${ }^{39}$

After referring to all the Hadīth books, the phrase "fa innahi kanat fi him al-a'äjib" is found in another Hadith or in another book:

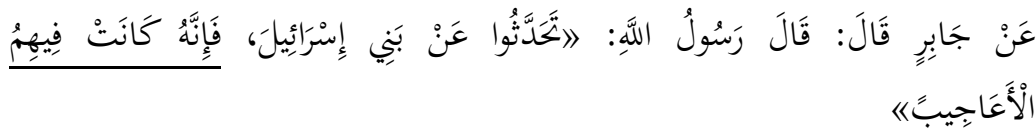

"From Jābir said; Rasul said: "Tell from the Banī Isrā̄īl and there is no sin, truly they (Ban̄i Isrā'îl) have a miracle" (Narrated by 'Abd b. Hamīd). ${ }^{40}$

\footnotetext{
39 Abū Bakr 'Abd al-Razzāq b. Himām b. Nāfiq al-Ḥumayrī al-Yamān̄̄ alȘan'ānī, al-Musannaf 'Abd al-Ražàq al-San'ānì, Vol. 6 (Beirut: al-Maktab al-Islāmī, 1403), 110.

40 Abū Muḥammad 'Abd al-Ḥamīd b. Hamīd b. Naṣr al-Kassī, al-Muntakhab min Musnad 'Abd b. Hamid, Vol. 1, No. 1156 (Kairo: Maktabat al-Sunnah, 1408), 349.
} 
Similarly, the argument of Shahrūr about the narration of Jābir b. 'Abd Allāh in the Musnad al-Shäfic number 1.177 is that the Hadith under debate cannot be found, and even the Hadith number 1.177 is not like different from the Hadith intended by Shahrūr. However, the Hadīth narrated by Jābir b. 'Abd Allāh can be found in the Musnad Ahmad, but with different text (matn):

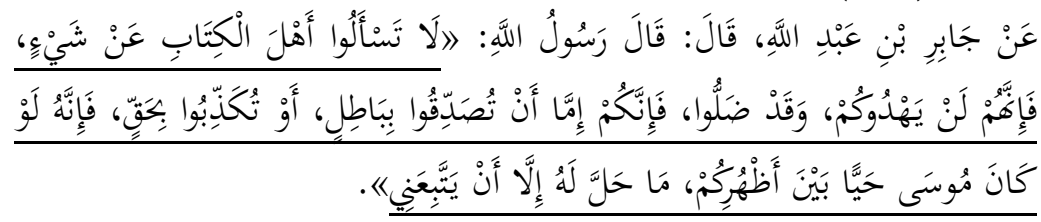

"From Jābir Ibn 'Abd Allah, said: The Apostle said: "Do not ask the People of the Book about something, in fact they will not be able to give you guidance, and indeed they have gone astray, then in fact you may justify deceit or may lie truth. Indeed, if Musa was still alive among you, he would not have legalized himself except to follow me" (Narrated by Aḥmad b. Hanbal). ${ }^{41}$

After (sanad and matn criticism), it can be asserted that the Hadìth narrated by 'Abd al-Razzāq is categorized as the Hadīth with weak transmitters (daif al-sanad). In the Hadith, there is a narrator from mursal täbi in (no mention of the narrator from täbi ìn) between Zayd b. Aslam and Ibn Jurayj, and also mursal sahabi (no mention of the narrator from companions) between the Zayd b. Aslam and the Prophet, since Zayd was a täbi'in (follower). ${ }^{42}$

However, the Hadīth text (matn) of 'Abd al-Razzāq does not contradict with the Prophet's saying that there is a prohibition of asking the People of the Book about Islam or tawhid (monotheism), because they have misled their religion. Likewise, someone cannot accept news from the People of the Book because their testimony has been rejected. ${ }^{43}$ However, it is permitted to tell the story about the Banī Isrā̄îl as far as it is

41 Abū 'Abd Allāh Aḥmad b. Muhammad b. Hanbal b. Hilāl b. Asad alShaybānī, Musnad al-Imām Aḥmad b. Hanbal, Vol. 22, No. 14631 (N.p.: Mu'assis al-Risālah, 1421), 468.

42 Ibid., 468-469.

43 Aḥmad b. 'Alī b. Hajar Abū al-Faḍl al-'Asqalānī, Fatḥ al-Bārì Shaṛ̣ Saḥ̣̄̄ alBukìàrì, Vol. 5 (Beirut: Dār al-Ma'rifah, 1379), 292. 
known that the story is not a lie; however, it is not allowed to lie about the story of Banī Isrā̄îl, while there are rukhsab (relief) in delivering the stories of the Banī Isrāî̀l. However, the delivery of the Israelite stories must be accompanied with transmitters (sanad) as there has been long temporal distance to the Banī Isrā'̄î..$^{44}$ It is permitted to tell about only good things, but it is not allowed to deliver bad things and a lie. The Prophet allowed the companions to tell about Banī Isrā̄îl under several conditions, but prohibited the inclusion of the stories about Banī Isrā'îl into the Hadīth. ${ }^{45}$

After scrutinizing the Hadiths narrated by 'Abd Ibn Hamīd it can be categorized as the Hadith of da if al-sanad, because one of the narrators in the Hadīth, al-Rabì' ibn Sa'ad al-Ju'fí, is a narrator whose identity is unknown (majbül häl). ${ }^{46}$

Basically, the phrase in the Hadith of 'Abd b. Hamìd "tahaddathī 'an Bani Isrä î̀" does not contradict with what the Prophet said about conditions as explained above. Meanwhile, the interpretation of the phrase " $f a$ innahù kannat fỉbim al-a'ajizib" regarding to the miracle and strangeness of the story of Banī Isrā̄ill needs to fulfil the conditions put by the Prophet, although the story is about good thing (in line with Islam), not a false story, ${ }^{47}$ and contradict Islamic law. When the story is contradictory to Islam, it will be rejected or considered as khurafät (superstitions). ${ }^{48}$

44 Abū Sulaymān Ḥamad b. Muḥammad b. Ibrāhīm b. al-Khațāōb al-Basrī, Ma'älim al-Sunan Sharḥ Sunan Abi Däwud, Vol. 4 (Halb: al-Maṭba'ah al-'Ilmīyah, 1351), 187.

${ }^{45}$ Muhạmmad Ashraf b. 'Alī b. Amīr b. 'Alī Ibn Haydar Abū 'Abd al-Raḥmān Abādī, 'Awn al-Ma'büd Sharh Sunan Abì Dāwūd wa Ma'abü Häshiyat Ibn al-Qayyim: Tahdhìb Sunan Abì Dāwūd, Vol. 10 (Beirut: Dār al-Kutub al-'Ilmīyah, 1415), 69.

${ }^{46}$ Shams al-Dīn Abū 'Abd Allāh Muhammad b. Aḥmad b. 'Uthmān b. Qaymār al-Dhahabī, Mĩạn al-I'tidāl fì Naqd al-Rijäl, Vol. 2 (Beirut: Dār al-Ma'rifah, 1382), 40; Al-Sayyid Abū al-Ma'āṭ̄ al-Nūrī Aḥmad 'Abd al-Razzāq 'Id Mạ̣mūd Muhammad Khalīl, Mawsū'at Aqwäl al-Imām Aḥmad b. Hanbal fì Rijäl al-Hadìth wa Tlalibi, Vol. 1 (N.p.: 'Ālim al-Kutub, 1417), 367.

47 Muḥammad b. Muḥammad b. Suwaylim Abū Dhuhbah, al-Isrä̀ithyyāt wa alMawdū'ät fì Kutub al-Tafsìr (N.p.: Maktabat al-Sunnah, n.d.), 107.

48 Abū Zakariyyā Maḥyā al-Dīn Yahyā b. Sharf al-Nawawī, Sharḥ al-Arba'in alNawawi, Vol. 12 (N.p.: n.p., n.d.), 27. Ibrāhīm b. Muḥammad b. Muḥammad Kamāl al-Dīn b. Aḥmad b. Husayn Burhān al-Dīn b. Ḥamzah al-Husaybī alDimashqī, al-Bayān wa al-Ta'rîf fi Asbäb Wurüd al-Hadith al-Sharif, Vol. 2 (Beirut: Dār al-Kutub al-'Arabī, n.d.), 59. 
It is also required not to shake the heart of a Muslim when he hears stories of miracles from the Banī Isrā̄îl. ${ }^{49}$

It is important to note, therefore, that Shahrūr's accusation that all Hadìths are mudraj with the story Isra'illiyāt is not valid, because Shahrūr's arguments on the basis of Hadīth are not evident. The first Hadith which is used as an argument is neither found in the Hadīth book mentioned by Shahrūr nor in other Hadith books. While the second Hadith is considered as a Hadith mudraj by Shahrūr himself, namely by inserting the text (matn) of Hadiths from other narrations into the very Hadith which is used as an argument which leads to the manipulation of the evidence. In the discipline of Hadīth, such arguments are rejected..$^{50}$

The first interpretation of the verse al-qur'an by Shahrūr that neither Hadith nor Sunnah is the revelation from Allah, along with his denial of the term "al-waby al-thän” (second revelation) in alNajm [53]: 3-4, can be regarded as not correct. The interpretation of the verse (linguistically) "wa mà yantiqu 'an al-hawa $\vec{a}$ " is "nothing was uttered by the Prophet Muhammad according to the will of his passions." Meanwhile, the phrase "in buwa illa waby yühạ" means "the utterance is nothing but a revelation revealed (to him)". It can also be interpreted that the word "yantiqu" means what is said by the Prophet Muhammad. Meanwhile, the word "buwa" means "nutqu al-nabl" or the words of the Prophet Muhammad, or everything the Prophet said. ${ }^{51}$ The translation of all the words "the Prophet's speech" is the Qur'ān and Hadīth, because the Hadìth (Sunnah) is an interpretation of the Qur'ān. Thus, the word "buwa" means the Qur'ān and the Hadith of the Prophet. ${ }^{52}$ If the meaning

49 Abū al-Ḥasan 'Ubayd Allāh b. Muḥammad 'Abd al-Salām b. Khān Muḥammad b. Amān Allāh b. Hishām al-Dīn al-Raḥmānī, Muru'āh al-Mafātīh Sharḥ Mishkeāt al-Maṣäbịh, Vol. 1 (Benares India: Idārat al-Buhūth al-'Ilmīyah wa al-Da'wah wa al-Iftā’, 1404), 301-302.

${ }^{50}$ Rif at b. Fawzī 'Abd al-Mutțalib, Tawthiq al-Sunnah fì al-Qarn al-Thānì al-Hijrah Asāsabū wa Ittijāhätihì (Mesir: Maktabat al-Khanā Najī, n.d.), 296.

${ }^{51}$ Ibrāhīm b. al-Sarī b. Sahl Abū Ishāq al-Zajāj, Ma'ānì al-Qur'ān wa I'rābih, Vol. 5 (Beirut: 'Alim al-Kutub, 1408), 70.

52 Abū 'Abd Allāh Muḥammad b. Aḥmad b. Abī Bakr b. Farj al-Anșārī alKhazrazī Shams al-Dīn al-Qurțbī, al-jāmi li Aḅkām al-Qur'ān (Tafsìr al-Qurtubì), Vol 13 (Kairo: Dār al-Kutub al-Miṣrīyah, 1384), 85; Darūzat Muḥammad 'Azat, al-Tafsìr al-Hadìth, Vol. 2 (Kairo: Dār al-Kutub al-'Arabìyah, 1383), 78. 
of the word "buwa" means al-Qur'àn, then the question arises: is what the Prophet said only the Qur'ān? Is the Hadith not the Prophet's words? Are the words which came out of the mouth of the Prophet not a revelation?

The interpretation of the verse is not the same as Shahrūr's argument, but contradictory. The Prophet could not have said anything wrong, since what he said was an evidence or an argument from Allah. In another commentary it is stated that what was revealed to the Prophet came from Allah, and through the Jibril was conveyed to the Prophet. In other words, all the words that came out of the Prophet's mouth were revelations (not the Prophet's passions) and that the Prophet's words were revealed from Allah through Jibrīl (including the Qur'ān and Hadīth). This can be proven by the evidence about the incident when the Prophet committed mistake in ijtibäd, then Allah rebuked the Prophet and provided a solution by revealing the verse related to the incorrect Prophet's ijtihäd. ${ }^{53}$

Shahrūr argues that the damir "buwa" has nothing to do with the word "yantiqu," and the meaning of the word "buwa" does not refer to the Qur'ān, but contains another meaning. This is because the Qur'ann is the words of the Prophet verbatim form Allah, while the word "yantiqu" means everything that was said by the Prophet. As a result, the word "bunva" and the word "yantiqu" are related to each other, as these explain the meaning and type of words uttered by the Prophet. In this context, the Qur'ān is the words of the Prophet that come from Allah, while the Hadiths are the words of the Prophet that come from the Prophet himself. ${ }^{54}$

It can be explained that the words of the Prophet (both the Qur'ān and Hadìth) are not based on the will of his desires and have nothing to do with the fluctuating state of his soul. This is in accordance with the explanation of the Qur'ān in al-Hashr [59]:

\footnotetext{
53 Abū Muḥammad Sahl b. 'Abd Allāh. Yūnus b. Rafí' al-Tustarī, Tafsìr al-Tustarì, Vol. 1 (Beirut: Dār al-Kutub al-'Ilmìyah, 1423), 156; al-Ṭabarī, Jāmi` al-Bayān, Vol. 22, 498.

${ }^{54}$ Abū Muḥammad Makkī b. Abī Ṭālib Ḥammūsh b. Muḥammad b. Mukhtār alQaysī al-Qīrāwānī al-Andalūsī al-Qurțubī al-Mālikī, al-Hidāyah ilā Bulūgh alNihāyah fi Tlm Ma'āni al-Qur'ān wa Tafsìih wa Aḅkāmih wa Jumal min Funūn 'Ulūmih, Vo. 11 (N.p.: Majmū' Buhūth al-Kitāb wa al-Sunnah, 1429), 7142.
} 
$7,{ }^{55}$ and the Hadith of the Prophet which is relevant to asbāb alnuгül (the causes of revelation) of al-Najm [53]: 3-4, implying that all of what the Prophet said (including the Qur'ān and Hadìth) is haq (truth), ${ }^{56}$ namely:

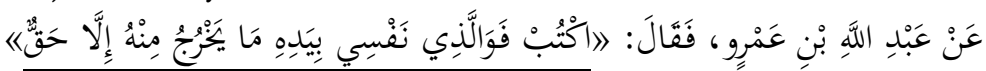

"From 'Abd Allāh b. 'Amr, said: He said: 'Continue your writing, then by God, whose soul is in His grasp, nothing comes out of my mouth but only rights (right)" (Narrated by Abū Dāwūd). ${ }^{57}$

The second interpretation of the verse al-qur'an by Shahrūr that Hadith is " $m \bar{a}$ dhahaba ilayh al-nabl" which means all forms of the Prophet's ijtihäd by providing evidence and colliding with the chapter 'Abasa [80]: 1-3, al-Anfāl [8]: 67 and al-Tahrīm [66]: 1, seems incorrect. The incident depicted in the chapter 'Abasa [80]: 1-3 had a specific cause of revelation (sabab al-nuzūl). It is known that the revelation of 'Abasa [80]: 1-3 was related to the coming of the blind Ibn Ummi Maktūm to the Prophet, wanting to be instructed and convert to Islam. The incident occurred when the Prophet was giving direction to the Quraysh leaders to convert to Islam which led the Prophet to ignore or reject the blind. Rejection of the Prophet was marked by the Prophet's sour face when he saw Ibn Ummi Maktūm (not verbal rejection). The Prophet did not pay attention to what Ibn Ummi Maktūm said because the former still dealt with the Quraysh leaders. ${ }^{58}$ This is in accordance with the Hadith of the Prophet narrated by al-Tirmīdhī. ${ }^{59}$

Likewise, the incident mentioned in al-Anfāl [8]: 67 has asbāb al-nuzūl. It is known that al-Anfāl [8]: 67 was revealed because

55 Abū 'Abd Allāh Muḥammad b. Idrīs b. al-'Abbās b. 'Uthmān b. Shāfi'ī b. 'Abd al-Muttalib b. 'Abd Manāf al-Qurayshī al-Shāfi'ī, Tafsìr al-Imām al-Shāfi' ', Vol. 3 (Saudi Arabīyah: Dār al-Tadmīìiyah, 1426), 1329.

${ }^{56}$ Abū al-Fidā' Ismāî̀l b. 'Umar b. Kathīr al-Qarashī al-Bașrī al-Dimashqī, Tafsìr al-Qur'ān al-'Ažim (Tafsìr Ibn Kathìr), Vol. 7 (N.p.: Dār Ṭayyibah, 1420 ), 443.

57 Abū Dāwūd Sulaymān b. al-Ash'ath b. Ishạa b. Bashīr b. Shadād b. 'Amr alAzadī al-Sijistānī, Sunan Abì Dāwūd, Vol. 3, No. 3646 (Beirut: al-Maktabat al'Așrīyah, n.d.), 328.

${ }^{58}$ Muḥammad b. 'Alī b. Muḥammad b. 'Abd Allāh al-Shawkānī al-Yamanī, Fatḥ al-Qadìr, Vol. 5 (Beirut: Dār Ibn Kathīr, 1414), 467.

${ }^{59}$ Muḥammad b. 'Īsā b. Sawrah b. Mūsā b. al-Ḍaḥāk Abū 'Īsā al-Tirmīdhī, Sunan al-Tirmidhì, Vol 5, No. 3331 (Mesir: Muștafā al-Bābī al-Ḥalbī, 1395), 432. 
there had been disputes among the companions of the Prophet during the war of Badr regarding prisoners. 'Umar wanted to kill all prisoners of the war that led to the full victory of Muslims. However, Abū Bakr disagreed and wanted to release the prisoners with a ransom of 4000 dinars. The Prophet decided to choose the opinion of Abū Bakr, and 'Umar responded: "It is not proper for the Prophet to have a prisoner before he can paralyze his enemies on earth". After that, there came the verse that supported what "Umar said, thus the Prophet chose to kill the enemies and prisoners to ensure the victory of Muslims in the battle of Badr. ${ }^{60}$

The incident mentioned in al-Tahrim [66]: 1 has also asbäb alnuгūl. Al-Tahrim [66]: 1 was revealed when the Prophet had intercourse with his slave wife, Māriyah al-Qibțìyah at Ḥafṣah’s house, while at that time Hafșah was not at home. Then, she came and objected with what had been done by the Prophet in her house. The Prophet told Hafṣah that she (Māriyah Qibțìyah) was baram (forbidden) for me. The Prophet did this to seek the pleasure of the Prophet's wives by stating that Māriyah Qibțìyah is forbidden for him. ${ }^{61}$

In these verses, there are explainations about the mistakes of the Prophet in his ijtihäd which are then corrected by Allah through the revelation of the verse which guide to what the Prophet should do. Shahrūr's mistake lies in his rejection of the Hadith by stating that it was the result of the Prophet's ijtibad, by using the evidence from the Qur'ān about the Prophet's mistake. However, the Prophet's misdeeds were not something used as the basis for law in Islam. Instead, Allah had rebuked and provided a solution by revealing a verse, thus making the Prophet free from mistakes in his actions.

Shahrūr uses the evidance from the Qur'ān or Hadīth which indicates that the Hadith is the result of the Prophet's ijtibäd which has no relevance to the Qur'ān, or that the Hadìth is not based on Allah's order, or that there is no warning and a solution from Allah through the revelation of the Qur'ānic verses. Therefore, Shahrūr

\footnotetext{
${ }^{60}$ Abū al-Hasan Maqātil b. Sulaymān b. Bashīr al-Azadī al-Balakhī, Tafsìr Maqātil b. Sulaymān, Vol. 2 (Beirut: Dār Ihyā̄’ al-Turāth, 1423), 129.

${ }^{61}$ Al-Mālikī, al-Hidāyah ilā Bulūgh al-Nỉāyah, Vol 12. 7561-7564.
} 
strongly asserts that the Hadìth is the result of the Prophet's ijtihäd himself, not an order from Allah.

The third interpretation of the verse by Shahrūr is that the Prophet and his companions did not consider the Hadith as revelation from Allah. For Shahrūr, it is evident that neither the Prophet nor his companions ordered to collect, write or record Hadiths or as the Prophet had ordered to write the Qur'ān on the grounds of avoiding the mixture between revelations, the Qur'ān, and Hadìth. This viewpoint of Shahrūr can be said as weak, since the argument used in this regard, al-Hijr [15]: 9 is interpreted literally, thus . considering that the Qur'ann is preserved by writing from the beginning is said to be from the Prophet, while the Hadìths are not. He also questions why the Qur'ān and Hadīth were not written simultaneously or the Prophet assigned his companions to document both the Qur'ān and Hadīth.

In the interpretation of the chapter al-Hijr [15]: 9, the meaning of the phrase "wa innà lahü laḥafizùn" is that Allah keeps the Qur'ān by making it easier for the companions at that time to memorize and recite the Qur'ān, so, the Qur'ān is free from additions, subtractions and deviations. ${ }^{62}$ Based on a historical point of view, one can argue that the Qur'ān was sent down gradually to the Prophet and passed on to Muslims at that time gradually, so the Prophet's Hadìth is an interpretation of the Qur'ān. This actually strengthens the statement that the Prophet ordered to write down the Qur'ān and postpone (with a temporary ban) for writing other than the Qur'ān (in this case Hadīth) on the grounds that it is to be not mixed. At the beginning of Islam, the Qur'ān was still in the form of kalàm Allāh (there was no name for the Qur'ān). However, after Islam developed, the name of al-Qur'ān emerged to designate the corpus of collected verses revealed to the Prophet. The terms al-Qur'ān and Hadīth originated from the words of the same Prophet: that is, the Qur'an came down by the words (verbatim) from Allah, conveyed through the words of the Prophet, while the

62 Abū al-Hasan 'Alī b. Muḥammad b. Muhammad b. Habīb al-Bașrī alBaghdādī al-Māwardī, Tafsìr al-Māwardì: al-Nukat wa al- Uyūn, Vol. 3 (Beirut: Dār al-Kutub al-'Ilmīyah, n.d.), 149; Muḥammad b. 'Abd al-Raḥmān b. Muḥammad

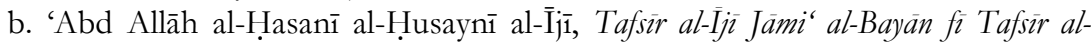
Qur'àn, Vol. 2 (Beirut: Dār al-Kutub al-'Ilmìyah, 1424), 306. 
Hadiths were conveyed through the words of the Prophet himself. ${ }^{63}$

It is important to raise such a question as why the Prophet did not assign some companions to write down the revealed verses and some others to collect and write Hadith that came out of himself at the same time. The Prophet ordered some companions to write the revealed verses on the palm fronds (not yet in the form of mushaf) at that time because the revelation has not been complete yet before the Prophet died (as evidenced by the revelation of the last verse (al-Mă'idah [5]: 3) at the farewell pilgrimage (bajjat al-wadāa) in the year 10 after bijrah (the Prophet died in the year 11 after bijrab). The writing of the revealed verses of the Qur'an can be proven by the correction of the writing of Zayd b. Thābit by the Prophet. The Prophet also ordered some companions to write Hadiths after Islam spread, but it was not mandatory. The companions with low or weak memorization capacity are encouraged to write down Hadiths, while those with high capacity are not. ${ }^{64}$

It is admitted from historical perspective that, the Qur'ān was revealed in Arabia, dan therefore to a great degree represent the Arab sociological and historical milieu at that time. The Arabs are known as not strong at reading, writing and arithmetic, ${ }^{65}$ they are very good in memory. ${ }^{66}$ In this context, the Qur'ān and Hadīth of the Prophet have been memorized from the beginning of the Prophetic message. Despite the fact that the companions did not

63 Muhammad 'Umar Hawayh, Nuzūl al-Qur'ān al-Karim wa Tärīkhì wa mā Yata'allaqu Bì (Madinah: Majmū' al-Muluk Faḥd, n.d.), 28; Khālid b. 'Abd alRaḥmān b. 'Alī al-Jarīsī, Mu'allim al-Tajwìd (N.p.: n.p., n.d.), 20; 'Abd al-Wadūd Maqbūl Ḥanîf, Nuzūl al-Qur'ān wa al-Ināyah Bì fí 'Ahd al-Nabì (Madinah: Majmū' al-Muluk Faḥ, n.d.), 14.

${ }^{64}$ Muḥammad Ṭāhir b. 'Abd al-Qādir al-Kurdī al-Makkī al-Shāfíī al-Khaṭtāt, Tärikh al-Qur'àn al-Karim (Hijāz: Maṭa'at al-Fath bi Jiddah, 1365), 20-22; al'Asqalānī, Fatḥ al-Bārì, Vol. 1, 210.

65 Aḥmad b. Muṣtafā al-Marāghī, Tafsìr al-Marāghì, Vol. 28 (Mesir: Shirkat Maktabat Muștafā al-Bābī al-Halbī, 1365), 94; al-Yamānī, Faṭ̣ al-Qadìr, Vol 2. 287.

66 'Abd al-'Aẓīm Ibrāhīm Muhammad al-Maṭ'anī, al-Shubhāt al-Thalāthūn alMuthārah li Inkērr al-Sunnah al-Nabawīyah 'Ard wa Tafnìd wa Naqs (N.p.: Maktabat Wahbah, 1420), 101; Muḥammad Ḥusayn Haikāl, Hayāt Muhammad wa Ālih wa Sallam (N.p.: n.p., n.d.), 31. 
write down the Hadiths due to their strong memory, there were in fact few companions who wrote the Hadith of the Prophet, such as 'Abd Allāh b. 'Amr b. al-'Āṣ who gave a title for his work alSádiqah. In addition, the Prophet allowed this companion to write down everything the Prophet said (see Hadith Ahmad b. Hanbal No. 3.646). ${ }^{67}$

It has been recorded in Islamic history that the Prophet ordered his companions to write down Hadiths at the time after the conquest of the city of Mecca. The event occurred when the Prophet gave a sermon after the conquest of the city and one of his companions from Yemen, Abū Shah, who was told to write down the Prophet's sermon. The Prophet then ordered his companions to write down the sermon (the prophetic Hadith) for Abū Shah. Many companions were wondered what to write, and therefore one of the companions gave an explanation by writing the Prophet's sermon. ${ }^{68}$ This is in accordance with the Hadith:

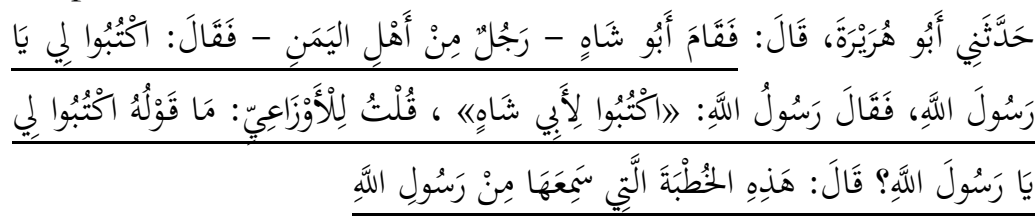

"Abū Hurayrah said; Then stood up Abū Shah, a resident of Yemen and said: 'Hi Messenger of Allah, write for me?' Rasulullah said: 'Write for Abū Shah.' Said, al-Walīd b. Muslim; I asked al-Awza'1: 'What did he mean by asking me to write it down, hi Messenger of Allah?' He said: 'The contents of the sermon he heard from the Messenger of Allah." ${ }^{\prime 69}$

Abu Shah was a Persian descendant who lived in Yemen, thus his capacity of memorization was not as strong as the Arabs. ${ }^{70}$ This evidence indicates that the writing culture was not from the Arabs because they mostly relied on memorization. The Hadith is a substitute for the new law, because the Hadith that prohibited the

\footnotetext{
${ }^{67}$ al-Sibā̄īe al-Sunnah wa Makēnatuhā, 76-78.

${ }^{68}$ Ibid., 76-78.

${ }^{69}$ Muḥammad b. Ismāềl Abū 'Abd Allāh al-Bukhārī al-Ju'fî, al-Jāmi' al-Musnad alSab̄ḥ al-Mukhtasar min Umür Rasūl wa Sunanih wa Ayyämih (Sahịh al-Bukhäri), Vol. 3, No. 2.434 (N.p.: Dār Ṭauq al-Najāh, 1422), 125.

70 Abū al-Faḍl Aḥmad b. 'Alī b. Muḥammad b. Aḥmad b. Ḥajar al-'Asqalānī, alIsābah fì Tamyìz al-Sahābah, Vol. 7 (Beirut: Dār al-Kutub al-'Ilmīyah, 1415), 171.
} 
writing of the Qur'ān has been abrogated (mansükh). Therefore, it is then permitted to write Hadīth as 'Alī b. Abī Ṭālib did with his sahifah. It was also the case with the inscription of 'Amr b. Hazm about faräid (inheritance law), sunan al-Nabī (Sunnah of the prophet), diyat and also about Abū Bakr. The prohibition of writing the Qur'ann in early Islam is intended to avoid mixing the revealed Qur'ān with Hadīth of the Prophet. However, when examined historically it is relevant to mention that the Hadith about the prohibition of writing other than the Qur'ān was the Hadith of the Prophet in Makkah, while the Hadīth that permitted the writing of Hadīth was the Hadīth of Madinah, as indicated by the time of the event when the Prophet said the Hadith. ${ }^{71}$

The mistake made by Shahrūr was to equate the conditions during the early days of Islam with the conditions when Islam already developed, as well as the current existing writing techniques, and the patterns, behavior and characteristics of the Arabs in the past and in the present. It is very clear that the Arabs in the past was characterized by their reliance on their memorization, whereas most people today rely upon their writing capacity.

The fourth interpretation of the verses of the Qur'an carried out by Shahrūr is that the Sunnah changes and transforms, since the Qur'ān never explains the eternity of the Sunnah. However, the statement that the Sunnah is tentative is not justified by the Qur'ān.

With regard to al-Anfāl [8]: 38, this verse is often considered as threatening the unbelievers to stop their infidelity. Shahrūr has mistaken to mean the word "madat." This word comes from the word madà-yamdì which means khala (go through/pass), ${ }^{72}$ dhahaba (go), ibta'ada (disappear), nafadba (complete, perform, implement), istamarra (continue, forward, skip, repeat). ${ }^{73}$ However, Shahrūr defines the word "madal" as has been missed or has expired and

\footnotetext{
71 Abū Zakariyā Maḥy al-Dīn Yahyā b. Sharf al-Nawawī, al-Manhāj Sharh Sahīḥ Muslim b. al-Hajjäj, Vol. 9 (Beirut: Dār Ihyyā’ al-Turāth al-'Arabī, 1392), 129-130; and ibid., Vol. 18, 130.

${ }^{72}$ Majid al-Dīn Abū Ṭāhir Muhammad b. Ya'qūb al-Fayrūzī Ābādī, al-Qāmūs alMubịt, Vol. 1 (Beirut: Mu’assis al-RisĀlah, 1426 H), 1335.

73 'Umar, Mu'jam al-Lughah, Vol. 3, 2106.
} 
been replaced with a new one. Lexically, the word "madat" has several meanings and one of the meanings is "has passed," but it refers to something like what God did to the unbelievers in the past. It can be maintained that the word madat in this verse can be meant as having passed or has done, while the meaning of the word istamarra is continuing and repeating. This verse contains a threat from Allah to the unbelievers if they return to their disbelief, so that Allah will repeat what $\mathrm{He}$ has done, that is, destroying the unbelievers. ${ }^{74}$

The misinterpretation made by Shahrūr also occurs in the meaning of the word "khalat." This word comes from the word khalä-yakblü which means madà (go/pass), dhababa (go), taqaddama (pass). ${ }^{75}$ According to Shahrūr, the word "khalat" means pass or has been missed or has expired and was replaced with a new one. Lexically, the word "khalat" does have several meanings, and one of the meanings is "has passed" but it refers to something like what God has done (destroyed) to the former people who were unbelievers, and does not mean it "has passed" then being replaced with a new one. The meaning given by Shahrūr is not correct, because he takes the verse literally, deviating from the meaning, and even uses the meaning of a synonym that is contradictory to his concept (namely anti-synonymity). The word "madat" and "khalat" have similar meaning: i.e., have passed (have been done or performed by Allah) and will continue or repeat. Therefore, it cannot be interpreted literally. ${ }^{76}$

From these two verses, it is clear that Shahrūr has misinterpreted and misconstrued the meaning and intention of the Qur'ānic verses by interpreting them literally and by changing the interpretation that distorts the definition of the Sunnah which is considered as tentative and changing all the time, even though the Sunnah does not change every time.

To a certain degree, Shahrūr's concept of Hadīth or Sunnah can be regarded as representing the tendency towards inkar al-

\footnotetext{
${ }^{74}$ Wahbah b. Muștafā al-Zuhaylī, al-Tafsìr al-Munir fì al-'Aqidah wa al-Sharíah wa al-Manhaj (al-Tafsìr al-Munir li al-Zuhayli), Vol. 9 (Damaskus: Dār al-Fikr, 1422), 321.

75 'Umar, Mu'jam al-Lughah, Vol 3, 691.

${ }^{76}$ Muhammad 'Al̄̄ al-Ṣābūnī, Mukhtasar Tafsìr Ibn Kathìr, Vol. 2 (Beirut: Dār alQur’ān al-Karīm, 1402), 308.
} 
Sunnah (the denial of the Prophet's traditions). This can be seen from his concept or definition that the Hadīth is the Qur'àn itself; the Hadìth is filled with stories of Isrā'iliyyāt; the Hadīth is a form of the Prophet's ijtibäd. In additions, his tendency to deny the Sunnah can be seen from and his concept: that Sunnah changes, depending upon a particular social and cultural backgrounds. society and produces certain and civilizations at each stage of its era, which is it is to support that Islam is suitable for each time and place (sälih li kulli zamān wa makān), a viewpoint which is not quite valid with regard to the above argument. ${ }^{77}$

\section{Conclusion}

It has been generally agreed that Hadiths is the second source of Islamic law. However, there emerges a scholar with contrasting viewpoints against this orthodox position, namely Muhammad Shahrūr. For some scholars, his criticism against the established view on Hadith and Sunnah represents the tendency towards the denial of the Prophet's tradition (inkearr al-Sunnab). Shahrūr is a contemporary thinker and researcher who rejects Hadīth and Sunnah as the second source of law in Islam. His argument is based on the point of view that the Hadīth is the Qur'ān itself. Moreover, he states that Hadīths are filled with the story Isrā'iliyyāt (the Biblical stories), accusing the Prophet as ignoring the writing and codification of Hadiths. However, based on critical scrutiny of sources presented above which includes the verses of the Qur'ān, the narratives of Hadīth, exegesis, historical accounts and linguistic works, this article concludes that Shahrūr's views and thought on the issue of Hadith are not supported with justified arguments and valid reading and understanding towards the meaning of various Qur'ānic verses.

\footnotetext{
77 Ṣālih al-Dīn Fawzān b. 'Abd Allāh al-Fawzān, Sharḅ al-Ușūl al-Thalāthah (N.p.: Mu'assis al-Risālah, 1427), 272; 'Abd al-Raḥmān b. Hammād 'Alī 'Umar, Dìn alHaq (Saudi Arabia: Wizārat al-Shu'ūn al-Islāmīyah wa al-Awqāf wa al-Da'wah wa al-Irshād, 1420), 80; Faḥd b. 'Abd al-Raḥmān b. Sulaymān al-Rūmī, alBadabiyāt fì al-Qur'ān al-Karim (Madinah: al-Jāmi'ah al-Islāmīyah, 1417), 11; Muhammad b. Șāliḥ b. Muḥammad al-'Uthaymīn, Tafsìr Juz' 'Am (Tafsìr alUthayminn) (Riyadh: Dār al-Tharayā, 1423), 84.
} 


\section{Bibliography}

Ābādī, Majid al-Dīn Abū Țāhir Muhammad b. Ya'qūb al-Fayrūzī. al-Qàmūs al-Muhìt, Vol. 1. Beirut: Mu'assis al-RisĀlah, $1426 \mathrm{H}$ Abādī, Muhammad Ashraf b. 'Alī b. Amīr b. 'Alī Ibn Ḥaydar Abū 'Abd al-Raḥmān. 'Awn al-Ma'büd Sharḥ Sunan Abi Dāwùd wa Ma'abū Hōashiyat Ibn al-Qayyim: Tabdhìb Sunan Abi Dāwüd, Vol. 10. Beirut: Dār al-Kutub al-'Tlmīyah, 1415.

Abidin, Zainal. Rethinking Islam dan Iman. Banjarmasin: IAIN Antasari Press, n.d.

'Arabī (al), Muḥammad b. 'Abd Allāh Abū Bakr. Aḅkām al-Qu'rān, Vol. 2. Beirut: Dār al-Kutub al-'Tlmīyah, 1424/2003.

'Asqalānī (al), Abū al-Fạ̣l Aḥmad b. 'Alī b. Muḥammad b. Aḥmad b. Hajar. al-Isāabah fì Tamyì al-Sahābah, Vol. 7. Beirut: Dār alKutub al-'Ilmìyah, 1415.

----. Fatḥ al-Bār Sharḥ Șahị̆ al-Bukhārī, Vol. 5. Beirut: Dār alMa'rifah, 1379.

'Azat, Darūzat Muhammad. al-Tafsìr al-Hadìth, Vol. 2. Kairo: Dār al-Kutub al-'Arabiyah, 1383.

Baghdādī (al), al-Khāțīb. al-Kifāyah fì 'Tlm al-Rìwāyah. Beirut: Dār alKutub al-'Tlmìyah, 2006.

Balakhī (al), Abū al-Ḥasan Maqātil b. Sulaymān b. Bashīr al-Azadī.

Tafsìr Maqātil b. Sulaymān, Vol. 2. Beirut: Dār Ihyyā’ al-Turāth, 1423.

Baṣrī (al), Qatādah b. Di'āmah b. Qatādah b. 'Azīz Abū al-Khațāāb al-Sudūsī. al-Näsih wa al-Mansükh. N.p.: Mu’assisat al-Risālah, 1418.

Baṣrī (al), Abū Sulaymān Ḥamad b. Muhammad b. Ibrāhīm b. alKhaț̣āb. Ma'älim al-Sunan Sharḥ Sunan Abì Dāwnd, Vol. 4. Halb: al-Matba'ah al-'Ilmīyah, 1351.

Clark, Peter. "The Shahrur Phenomenon; A Liberal Islamic Voice from Syria," Islam and Christian-Muslim Relations, Vol. 7. No. 3, 1996.

Dhahabī (al), Shams al-Dīn Abū 'Abd Allāh Muhammad b. Aḥmad b. 'Uthmān b. Qaymār Mĩ̄àn al-I'tidäl fì Naqd al-Rijäl, Vol. 2. Beirut: Dār al-Ma'rifah, 1382.

Dhuhbah, Muhammad b. Muhammad b. Suwaylim Abū. alIsräinyyyàt wa al-Mawdū'ät fi Kutub al-Tafsìr. N.p.: Maktabat alSunnah, n.d. 
Dimashqī (al), Abū al-Fidā' Ismā'îl b. 'Umar b. Kathīr al-Qarashī al-Bașrī al-Dimashqī, Tafsìr al-Qur'ān al-'Ažìm (Tafsìr Ibn Kathìr), Vol. 7. N.p.: Dār Ṭayyibah, 1420.

Dimashqī (al), Ibrāhīm b. Muḥammad b. Muḥammad Kamāl alDīn b. Aḥmad b. Husayn Burhān al-Dīn b. Hamzah alHusaybī. al-Bayān wa al-Ta'rif fi Asbäb Wurüd al-Hadith al-Sharif, Vol. 2. Beirut: Dār al-Kutub al-'Arabī, n.d.

Fawzān (al), Șālih al-Dīn Fawzān b. 'Abd Allāh. Sharḥ al-Ușūl alThaläthah. N.p.: Mu'assis al-Risālah, 1427.

Fitria, Vita. "Komparasi Metodologis Konsep Sunnah Menurut Fazlur Rahman dan Muhammad Syahrur," Asy-Syir'ab: Jurnal Ilmu Syari'ah dan Hukum, Vol. 45, No. I2, Juli-Desember 2011. Habīb, Sa'dī Abū. al-Qāmūs al-Fiqhìyah Lughah wa Iștilāḥ. Damascus: Dār al-Fikr, 1408.

Hanīf, 'Abd al-Wadūd Maqbūl. Nuzūl al-Qur'àn wa al-Ināyah Bì fì 'Ahd al-Nabi. Madinah: Majmū' al-Muluk Faḥd, n.d.

Hawayh, Muhammad 'Umar. Nuzūl al-Qur'ān al-Karim wa Tärikkbih wa mā Yata'allaqu Bih. Madinah: Majmū' al-Muluk Faḥd, n.d.

Haikāl, Muḥammad Husayn. Hayāt Muhammad wa Ālih wa Sallam. N.p.: n.p., n.d.

Ijjī (al), Muḥammad b. 'Abd al-Raḥmān b. Muḥammad b. 'Abd Allāh al-Ḥasanī al-Husaynī. Tafsìr al-İjì Jāmi' al-Bayān fì Tafsìr alQư'àn, Vol. 2. Beirut: Dār al-Kutub al-'Ilmīyah, 1424.

Ismāîil, Muḥammad Bakr. Dirāsāt fì 'Ulūm al-Qur'ān. N.p.: Dār alManār, 1419.

Ismail, Ahmad Syarqawi. Rekonstruksi Konsep Wabyu Mubammad Syahrur. Yogyakarta: eLSAQ Press, 2003.

Jarīsī (al), Khālid b. 'Abd al-Raḥmān b. 'Alī. Mu'allim al-Tajwñd. N.p.: n.p., n.d.

Jawīnī (al), 'Abd al-Mālik b. 'Abd Allāh b. Yūsuf b. Muḥammad alBurbān fì Ușūl al-Fiqh, Vol. 2. Beirut: Dār al-Kutub al-'Ilmìyah, 1418.

Jawzī (al), Jamāl al-Dīn Abū al-Farj 'Abd al-Raḥmān b. 'Alī b. Muhammad al-Musfi bi Akfi Abl al-Rasükh min Tlm al-Näsikh wa al-Mansǚkh. N.p.: Mu'assisat al-Risālah, 1418.

Jīzānī (al), Muḥammad b. Ḥusayn b. Ḥasan. Ma'álim Ușūl al-Fiqh Inda Abl al-Sunnah wa al-Jamāáah. N.p..: Dār Ibn al-Jawzī, 1427. 
Ju'fì (al), Muḥammad b. Ismā'īl Abū 'Abd Allāh al-Bukhārī. al-Jāmi' al-Musnad al-Sahīh al-Mukhtasar min Umür Rasūl wa Sunanih wa Ayyämih (Sahịh al-Bukhāri), Vol. 3, No. 2.434. N.p.: Dār Ṭauq al-Najāh, 1422.

Kassī (al), Abū Muhammad 'Abd al-Hamīd b. Hamīd b. Naṣr. alMuntakhab min Musnad 'Abd b. Hamid, Vol. 1, No. 1156. Kairo: Maktabat al-Sunnah, 1408.

Khalāf, 'Abd al-Wahhāb. Tlm Ușūl al-Fiqh. Mesir: Maktabat alDa'wah, n.d.

Khalīil, al-Sayyid Abū al-Ma'ātị al-Nūrī Aḥmad 'Abd al-Razzāq 'Id Maḥmūd Muhammad. Mawsū'at Aqwāl al-Imām Aḅmad $b$. Hanbal fi Rijäl al-Hadith wa Tlalihi, Vol. 1. N.p.: 'Ālim al-Kutub, 1417.

Khațtāt (al). Muḥammad Ṭāhir b. 'Abd al-Qādir al-Kurdī al-Makkī al-Shāfi'î. Tärikeh al-Qur'ān al-Karim. Hijāz: Maṭba'at al-Fath bi Jiddah, 1365.

Kurdi et al. Hermenetika al-Qur'an dan Hadis. Yogyakarta: Elsaq Press, 2010.

Ma'lūf (al), Louwis b. Naqula Zāhir. al-Munjid fì al-Lughah. Beirut: al-Maṭba'ah al-Kāthulīkìyah, 2010.

Mālikī (al), Abū Muhammad Makkī b. Abī Ṭālib Ḥammūsh b.

Muhạmmad b. Mukhtār al-Qaysī al-Qīrāwānī al-Andalūsī alQurțubī. al-Hidāyah ilā Bulügh al-Nibāyah fì 'Ilm Ma'ānì al-Qur'àn wa Tafsìih wa Aḅkāmih wa Jumal min Funūn 'Ulümih, Vo. 11.

N.p.: Majmū‘ Buhūth al-Kitāb wa al-Sunnah, 1429.

Marāghī (al), Aḥmad b. Muṣtafā. Tafsìr al-Maräghì, Vol. 28. Mesir: Shirkat Maktabat Muṣtafā al-Bābī al-Ḥalbī, 1365.

Maṭ'anī (al), 'Abd al-'Azīim Ibrāhīm Muhammad. al-Shubhāt alThaläthūn al-Muthärah li Inkär al-Sunnah al-Nabawìah 'Ard wa Tafnid wa Naqs. N.p.: Maktabat Wahbah, 1420.

Māwardī (al), Abū al-Ḥasan 'Alī b. Muḥammad b. Muhạmmad b. Ḥabīb al-Bașrī al-Baghdādī. Tafsìr al-Māwardī: al-Nukat wa alUyūn, Vol. 3. Beirut: Dār al-Kutub al-'Tlmìyah, n.d.

Muhạāsibī (al), Abū 'Abd Allāh al-Ḥārith b. Asad. Fahm al-Qur'ān wa Ma'ānīhi. Beirut: Dār al-Kindī, 1398.

Muqrī (al), Abū al-Qāsim b. Salāmah b. Nașr b. 'Alī al-Baghdādī. al-Näsikeh wa al-Mansūkeh. Beirut: al-Maktabat al-Islāmī, 1404. 
Mustaqim, Abdul. Epistemologi Tafsir Kontemporer. Yogyakarta: LKiS, 2010.

Muțalib (al), Rifat b. Fawzī 'Abd. Tawthiq al-Sunnah fì al-Qarn alThānì al-Hijrah Asāsahù wa Ittijāhātibì. Mesir: Maktabat al-Khanā Najī, n.d.

Nawawī (al), Abū Zakariyā Maḥy al-Dīn Yahyyā b. Sharf. al-Manhāj Sharh Sahịh Muslim b. al-Hajjāj, Vol. 9. Beirut: Dār Ihyā̄' alTurāth al-'Arabī, 1392.

Qāsimī (al), Muhammad Jamāl al-Dīn b. Muhammad Sa'īd b. Qādim al-Ḥalāq, Qawāid al-Tạ̣dìth min Funūn Muștalạ̣ alHadith. Beirut: Dār al-Kutub al-'Ilmìyah, n.d.

Qaț̣ān (al), Mannā' b. Khalīl. Mabāḥith fì 'Ulüm al-Qu'rān. Beirut: Maktabat al-Ma'ārif, 1421/2000.

Qurțubī (al), Abū 'Abd Allāh Muḥammad b. Aḥmad b. Abī Bakr b. Farj al-Anșārī al-Khazrazī Shams al-Dīn. al-Jāmi li Aḅkeàm alQur'ān (Tafsìr al-Qurtubi), Vol 13. Kairo: Dār al-Kutub alMișrīyah, 1384.

Raḥmānī (al), Abū al-Ḥasan 'Ubayd Allāh b. Muḥammad 'Abd alSalām b. Khān Muḥammad b. Amān Allāh b. Hishām al-Dīn. Muru'āh al-Mafätīh Sharḅ Mishkät al-Masābị̀, Vol. 1. Benares India: Idārat al-Buhūth al-'Ilmīyah wa al-Da'wah wa al-Iftā', 1404.

Rāzì (al), Abū Muḥammad 'Abd al-Raḥmān b. Muḥammad b. Idrīs b. al-Mundhīr al-Tamīmī b. Abī Ḥātim. Tafsìr al-Qur'ān al-'Ažìm li Ibn Abì Hātim, Vol. 10. Saudi Arabia: Maktabat Naẓār Muṣtafā al-Bāz, 1419.

Rūmī (al), Faḥd b. 'Abd al-Raḥmān b. Sulaymān. al-Badabiyàt fì alQur'ān al-Karim. Madinah: al-Jāmi'ah al-Islāmīyah, 1417.

----. Dirāsāt fì 'Ulūm al-Qur'àn al-Karim. N.p.: Huqūq al-Ṭab` Maḥūẓah, 1424.

Ṣābūnī (al), Muhammad 'Alī. Mukhtasar Tafsìr Ibn Kathìr, Vol. 2. Beirut: Dār al-Qur’ān al-Karìm, 1402.

Șan'ānī (al), Abū Bakr 'Abd al-Razzāq b. Himām b. Nāfiq alHumayrī al-Yamānī. al-Musannaf 'Abd al-Ražāq al-Ṣan'ānì, Vol. 6. Beirut: al-Maktab al-Islāmī, 1403.

Șawwāf (al), Muḥammad Munīr. Tahäfut al-Qirāah Mu'äsirah. Limmasol-Cyprus: al-Shawwāf li al-Nashr wa al-Dirāsāt, 1993. 
Salamī (al), Zayn al-Dīn 'Abd al-Raḥmān b. Aḥmad b. Rajab b. alHasan. Sharḥ Tla al-Tirmidhì. Yordania: Maktabat al-Manār, 1407.

Shāfi'ī (al), Abū 'Abd Allāh Muhammad b. Idrīs b. al-'Abbās b. 'Uthmān b. Shāfi'ì b. 'Abd al-Muțtalib b. 'Abd Manāf alQurayshī. Tafsìr al-Imām al-Shäfì̛, Vol. 3. Saudi Arabīyah: Dār al-Tadmīīìah, 1426.

Shāfíī (al), Abū Muḥammad al-Ḥusayn b. Mas'ūd b. Muḥammad b. al-Farā' al-Baghawī. Ma'älim al-Tanzìl fì Tafsìr al-Qur'àn (Tafsìr al-Baghawñ), Vol. 5. Beirut: Dār Ihyā̄' al-Turāth al-'Arabī, 1420 $\mathrm{H}$.

Shah, M. Awnul Abid. Islam Garda Depan; Mozaik Pemikiran Islam Timur Tengah. Bandung: Mizan 2001.

Shaḥūr, Muhammad. al-Sunnah al-Rasülīyah wa al-Sunnah alNabawìyah. Beirut: Dār al-Sāqī, 2012.

----. Islam dan Iman: Aturan-aturan Pokok, translated by M. Zaid Su'di. Yogyakarta: Penerbit Jendela, 2002.

-----. Metodologi Figib Islam Kontemporer, terj. Sahiron Syamsuddin. Yogyakarta: Kalimera, 2015.

-----. Prinsip dan Dasar Hermeneutika al-Qur'an Kontemporer. Yogyakarta: eLSAQ Prees, 2008.

----. Epistimologi Qur'ani: Tafsir Kontemporer Ayat-ayat al-Qur'ān Berbasis Materialisme-Dialektika-Historis, translated by M. Firdaus. Bandung: Penerbit Marja, 2015.

Shaybānī (al), Abū 'Abd Allāh Ạ̣mad b. Muḥammad b. Hanbal b. Hilāl b. Asad. Musnad al-Imàm Aḅmad b. Hanbal, Vol. 22, No. 14631. N.p.: Mu'assis al-Risālah, 1421.

Sijistānī (al), Abū Dāwūd Sulaymān b. al-Ash'ath b. Ishạa b. Bashīr b. Shadād b. 'Amr al-Azadī. Sunan Abì Dāwūd, Vol. 3, No. 3646. Beirut: al-Maktabat al-'Așrīyah, n.d.

Ṭabarī (al), Muḥammad b. Jarīr b. Yazīd b. Kathīr b. Ghālib alAmalī Abū Ja'far. Jämi' al-Bayàn fì Ta'mìl al-Qurān (Tafsìr alTabari), Vol. 23. N.p.: Mu'assis al-Risālah, 1420.

Tirmīdhī (al), Muḥammad b. 'Īsā b. Sawrah b. Mūsā b. al-Ḍaḥāk Abū 'Īsā. Sunan al-Tirmidhì, Vol 5, No. 3331. Mesir: Muștafāa alBābī al-Halbīi, 1395.

Tustarī (al), Abū Muḥammad Sahl b. 'Abd Allāh. Yūnus b. Rafí'. Tafsìr al-Tustarì, Vol. 1. Beirut: Dār al-Kutub al-'Ilmīyah, 1423. 
'Umar, 'Abd al-Raḥmān b. Ḥammād 'Alī. Din al-Haq. Saudi Arabia: Wizārat al-Shu'ūn al-Islāmīyah wa al-Awqāf wa al-Da'wah wa al-Irshād, 1420.

'Umar, Aḥmad Mukhtār 'Abd al-Hamīd. Mújam al-Lughah al'Arabìah al-Mu'äsirah, Vol. 1. N.p.: 'Ālim al-Kutub, 1429.

'Uthaymin (al), Muhammad b. Șālih b. Muhammad Musțtalạ alHadith. Kairo: Maktabat al-'Ilm, 1415.

----. Tafsì Juz' 'Am (Tafsìr al- 'Uthayminn). Riyadh: Dār al-Tharayā, 1423.

Yamānī (al), Muḥammad b. 'Alī b. Muḥammad b. 'Abd Allāh alShawkānī. Fath al-Qadìr, Vol. 5. Beirut: Dār Ibn Kathīr, 1414.

Yamanī (al), Nashwān b. Sa'īd al-Hamīrī. Shams al- 'Ulūm wa Dawa' Kaläm al-'Arab min al-Kalüm, Vol. 3. Beirut: Dār al-Fikr alMa'āṣir, 1420.

Zāhirī (al), Abū Muḥammad 'Alī b. Aḥmad b. Sa'īd b. Hazm alAndalusī al-Qurtubī. al-Näsikh wa al-Mansükeh fì al-Qur'än alKarìm. Beirut: Dār al-Kutub al-'Ilmīyah, 1406.

Zahw, Muhammad Abū. al-Hadìth wa al-Muhaddithūn. Kairo: Dār alFikr al-'Arabī, 1378.

Zajāij (al), Ibrāhīm b. al-Sarī b. Sahl Abū Ishạ̄q. Ma'ànī al-Qur'ān wa I'räbih, Vol. 5. Beirut: 'Alim al-Kutub, 1408.

Zarkashī (al), Abū 'Abd Allāh Badr al-Dīn Muhammad b. 'Abd Allāh b. Buhādir. al-Burbān fì 'Ulūm al-Qur'ān, Vol. 1. Beirut: Dār Ihyā̄' al-Kutub al-'Arabìyah, 1376.

Zuhaylī (al), Wahbah b. Muștafā. al-Tafsìr al-Munì fì al-'Aqìdah wa al-Sharíah wa al-Manhaj (al-Tafsir al-Munir li al-Zuhayli), Vol. 9. Damaskus: Dār al-Fikr, 1422.

Zurqānī (al), Muḥamamd 'Abd al-'Aẓ̇im. Manābil al-Irfān fì 'Ulūm al-Qur'ān, Vol. 1. N.p.: Maṭba' 'Īsā al-Bānī al-Ḥilmī, n.d. 